\title{
Exploring the phytochemical profile of Cytinus hypocistis (L.) L. as a source of health-promoting biomolecules behind its in vitro bioactive and enzyme inhibitory properties
}

\author{
Ana Rita Silva $^{\mathrm{a}, \mathrm{b}}$, José Pinela ${ }^{\mathrm{a}}$, Maria Inês Dias ${ }^{\mathrm{a}}$, Ricardo C. Calhelha ${ }^{\mathrm{a}}$, Maria José Alves ${ }^{\mathrm{a}}$, \\ Andrei Mocan $^{\mathrm{c}}$, Pablo A. García ${ }^{\mathrm{b}}$, Lillian Barros ${ }^{\mathrm{a}, * *}$, Isabel C.F.R. Ferreira ${ }^{\mathrm{a}, *}$

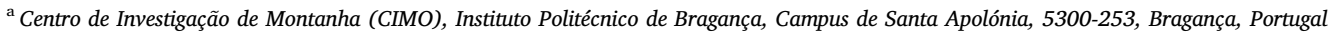

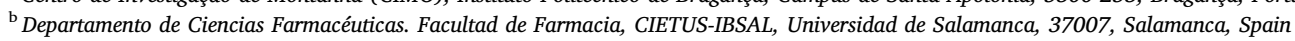 \\ ${ }^{\mathrm{c}}$ Department of Pharmaceutical Botany, "Iuliu Hațieganu" University of Medicine and Pharmacy, 23 Gheorghe Marinescu Street, 400337, Cluj-Napoca, Romania
}

A R T I C L E I N F O

\section{Keywords:}

Cytinus hypocistis (L.) L.

Phytochemical profile

Tannins

Bioactive properties

Cellular/enzymatic assays

\begin{abstract}
A B S T R A C T
Cytinus hypocistis whole plant and its three different parts (petals, stalks, and nectar) were chemically characterised and their biological properties evaluated. A total of 17 phenolic compounds were identified, being galloyl-bis-HHDP-glucose the most abundant. All the tested extracts showed high antioxidant capacity, with the petals exhibiting the most promising results both in the OxHLIA ( IC $_{50}=0.279 \mathrm{ng} / \mathrm{mL}$ ) and TBARS $\left(\mathrm{IC}_{50}=0.342 \mathrm{ng} / \mathrm{mL}\right)$ assays. For the antidiabetic and anti-tyrosinase enzyme inhibitory assays, the stalk extract presented the lowest $\mathrm{IC}_{50}$ values, $0.039 \mathrm{mg} / \mathrm{mL}$ and $0.09 \mathrm{mg} / \mathrm{mL}$, respectively. Regarding antibacterial activity, all tested extracts displayed broad-spectrum microbial inhibition against both Gram-positive and Gram-negative bacteria. Similarly, all extracts displayed effective anti-proliferation activity against four tested tumour cell lines (NCI-H460, HeLa, HepG2, and MCF-7), with no toxicity observed for a non-tumour cell line. Considering the anti-inflammatory activity, the petals showed the highest nitric oxide inhibition $\left(\mathrm{IC}_{50}=127 \mu \mathrm{g} / \mathrm{mL}\right.$ ). These results point $C$. hypocistis as a promising source of health-promoting biomolecules.
\end{abstract}

\section{Introduction}

Medicinal plants have been used as medicine by humans for thousands of years in the form of crude drugs such as teas, tinctures, poultices, and later through more sophisticated techniques as compound isolation (Balunas and Kinghorn, 2005). After a period of indifference, in which synthetic compounds were preferred, there is an increasing interest in studying the active principles behind plants therapeutic properties (Graça et al., 2016). The pharmaceutical industry faces unprecedented challenges, with fewer compounds being found, tested, and released to the public mainly due to the several drawbacks of the process to approve new drugs, humans have once again turned to Nature to mitigate the relative void of combinatorial chemistry to find new compounds (Phillipson, 2007).

Polyphenols are the largest and the most widespread group of secondary metabolites in plants. With a great variety of structures, ranging from simple compounds with few aromatic rings to highly polymeric substances, such as flavonoids, stilbenes, lignans, and phenolic acids.
These compounds are commonly found in both edible and inedible plants, and have been reported to have multiple biological effects (Okuda and Ito, 2011). Tannins, being one of the most structurally diverse polyphenols, have been reported to play a crucial role in plant defence against pathogens, herbivores and climatic changes. Structurally, tannins can be subdivided into two major groups: condensed tannins (or proanthocyanidins), which are of flavonoid origin, and hydrolysable tannins, which are defined as esters of gallic acid with a polyol moiety, mainly $\beta$-D-glucose (Petersen et al., 2010). The last group can be further subdivided into gallotannins and ellagitannins, and their basic building block is $\beta$-glucogallin (1-O-galloyl- $\beta$-D glucopyranose) (Petersen et al., 2010). Typical complex gallotannins are the addition of gallic acid moieties and the formation of depsidic metabonds between suitably positioned galloyl residues in the molecule. Ellagitannins, however, are derived from pentagalloylglucose through an oxidative linkage of the galloyl moieties, leading to the formation of $3,4,5,3^{\prime}, 4^{\prime}, 5^{\prime}$-hexahydroxydiphenoyl (HHDP) moieties; they are named after their characteristic hydrolysis product, ellagic acid, the dilactone

\footnotetext{
* Corresponding author.

** Corresponding author.

E-mail addresses: lillian@ipb.pt (L. Barros), iferreira@ipb.pt (I.C.F.R. Ferreira).
} 
of HHDP. Whereas gallotannins seem to be mainly restricted to woody dicotyledonous plants, ellagitannins are more widely spread in the plant kingdom (Petersen et al., 2010).

Cytinus hypocistis (L.) L. (Cytinaceae family) is an endophytic parasitic plant on various members of the Cistaceae family occurring in the Mediterranean region. Apart from used as famine food, it was also applied in a wide variety of traditional healthcare practices, including dysentery, tumour of the throat, and eye inflammation treatment (Zucca et al., 2015). Although its biological properties were potentially attributed to its hydrolysable tannin content, to the authors' best knowledge, it's chemical composition is largely unknown, and active biomolecules are not yet identified (Magiatis et al., 2001; Zucca et al., 2015). Therefore, the present work aims at chemically characterise $C$. hypocistis and evaluate its antioxidant, antibacterial, anti-tyrosinase, antidiabetic, anti-inflammatory and anti-proliferative properties.

\section{Materials and methods}

\subsection{Standards and reagents}

$\alpha$-Glucosidase from Saccharomyces cerevisiae, trichloroacetic acid, mushroom tyrosinase, sulforhodamine B, ellipticine, dexamethasone, trypan blue, lipopolysaccharide (LPS), Tris(hydroxymethyl)aminomethane, thiobarbituric acid (TBA), 2,2'-azobis(2-amidinopropane)dihydrochloride (AAPH), 3,4-dihydroxy-L-phenylalanine (L-DOPA), and Trolox (6-hydroxy-2,5,7,8-tetramethylchroman-2-carboxylic acid) were acquired from Sigma Chemical Co. (Saint Louis, MO, USA). pIodonitrotetrazolium chloride (INT) was acquired from PanReac AppliChem (Barcelona, Spain), and Tryptic Soy Broth (TSB) and Mueller-Hinton (MHB) from Biolab ${ }^{\circledR}$ (Hungary). Dulbecco's Modified Eagle's and RPMI-1640 mediums, fetal bovine serum (FBS), Hank's balanced salt solution (HBSS), L-glutamine, nonessential amino acid solution $(2 \mathrm{mM})$, penicillin/streptomycin solutions, trypsin, and EDTA were acquired from Hyclone (Logan, USA). Acetonitrile 99.9\%, of High Performance Liquid Chromatography (HPLC) grade, and dimethyl sulfoxide (DMSO) were acquired from Fisher Scientific (Lisbon, Portugal) and formic acid from PanReac (Barcelona, Spain). Phenolic compound standards (catechin, gallic acid, and ellagic acid) were purchased from Extrasynthese (Genay, France). All other chemicals were of analytical grade and purchased from common sources. Water was treated by means of a Milli-Q water purification system (TGI Pure Water Systems, Greenville, SC, USA).

\subsection{Sampling and extracts preparation}

Cytinus hypocistis (L.) L. subsp. macranthus Wettst plants were collected in July 2018 from the host species Halimium lasianthum subsp. alyssoides (Lam.) Greuter at three different locations in Castro Daire, Portugal. Plant identification, characterization, and preparation were conducted as previously described by Silva et al. (2019). Fig. 1-A shows how lyophilised plants were separated into four different samples, whole plant $(\mathrm{CH})$, petals $(\mathrm{PCH})$, stalks $(\mathrm{SCH})$ and nectar $(\mathrm{NCH})$. Hydroethanolic extracts were then prepared as described by Bessada et al. (2016) using ethanol/water $(80: 20, v / v)$ as extraction solvent.

\subsection{Phenolic profile characterization}

Phenolic compounds were determined by HPLC-DAD-ESI/MS ${ }^{\text {n }}$ (Dionex Ultimate 3000 UPLC, Thermo Scientific, San Jose, CA, USA) as previously described (Bessada et al., 2016). Detection was carried out with a DAD using $280 \mathrm{~nm}, 330 \mathrm{~nm}$, and $370 \mathrm{~nm}$ as the preferred wavelengths and a mass spectrometer connected to the HPLC system. Mass spectrometric detection was performed by means of a Linear Ion Trap LTQ XL (Thermo Finnigan, San Jose, CA, USA) equipped with an ESI source and spectrums were recorded in negative ion mode $(\mathrm{m} / \mathrm{z}$ $100-1700)$. The phenolic compounds were characterized according to their UV spectra, fragmentation pattern, their retention times, and comparison with available standards. For quantification, calibration curves were obtained from commercial standards: gallic acid $\left(\mathrm{y}=131538 \mathrm{x}+292163 ; R^{2}=0.9998 ; \mathrm{LOD}=0.68 \mu \mathrm{g} / \mathrm{mL}\right.$; $\mathrm{LOQ}=1.61 \mu \mathrm{g} / \mathrm{mL}) ;$ catechin $\left(\mathrm{y}=84950 \mathrm{x}+23200 ; R^{2}=0.9999\right.$; LOD $=0.17 \mu \mathrm{g} / \mathrm{mL} ; \mathrm{LOQ}=0.68 \mu \mathrm{g} / \mathrm{mL}) ;$ ellagic acid $(\mathrm{y}=26719 \mathrm{x}-$ 317255; $\left.R^{2}=0.9996 ; \mathrm{LOD}=0.10 \mu \mathrm{g} / \mathrm{mL} ; \mathrm{LOQ}=0.48 \mu \mathrm{g} / \mathrm{mL}\right)$. The results were expressed in $\mathrm{mg} / \mathrm{g}$ of extract.

\subsection{Evaluation of bioactive properties}

\subsubsection{Antioxidant activity}

The oxidative haemolysis (OxHLIA) and thiobarbituric acid reactive substances (TBARS) formation inhibition assays were performed following methodologies previously described by Lockowandt et al. (2019). Trolox was used as positive control.

OxHLIA assay. In a flat bottom 48 -well microplate, $200 \mu \mathrm{L}$ of erythrocytes in PBS $(2.8 \% \mathrm{w} / v)$ were mixed with $400 \mu \mathrm{L}$ of the extract samples (0.0625-2 $\mu \mathrm{g} / \mathrm{mL}$ in PBS); PBS was used as control and milli-Q water for complete haemolysis. After pre-incubation at $37^{\circ} \mathrm{C}$ for $10 \mathrm{~min}$ with shaking, AAPH (200 $\mu \mathrm{L}, 160 \mathrm{mM}$ in PBS) was added and the optical density $(690 \mathrm{~nm})$ was measured every $\sim 10 \mathrm{~min}$ in a microplate reader (Bio-Tek Instruments, ELX800) until complete haemolysis. The results were given as $\mathrm{IC}_{50}$ values, i.e., extract concentration $(\mathrm{ng} / \mathrm{mL})$ required to protect $50 \%$ of the erythrocyte population from the oxidative haemolysis for $\Delta t$ of $60 \mathrm{~min}$ and $120 \mathrm{~min}$.

TBARS assay. The brains were obtained from pig (Sus scrofa) of body weight $\sim 147 \mathrm{Kg}$, dissected and homogenized with a polytron in ice-cold Tris- $\mathrm{HCl}$ buffer $(20 \mathrm{mM}, \mathrm{pH} 7.4)$ to produce a $1: 2(\mathrm{w} / \mathrm{v})$ brain tissue homogenate which was centrifuged at $3000 \mathrm{~g}$ for $10 \mathrm{~min}$. The porcine brain supernatant $(1: 2, w / v ; 0.1 \mathrm{~mL})$ was incubated with the extract samples $(0.0625-2 \mu \mathrm{g} / \mathrm{mL}$ in water; $0.2 \mathrm{~mL})$ plus $\mathrm{FeSO}_{4}(10 \mu \mathrm{M} ; 0.1 \mathrm{~mL})$ and ascorbic acid $(0.1 \mathrm{mM} ; 0.1 \mathrm{~mL})$ at $37{ }^{\circ} \mathrm{C}$ for $1 \mathrm{~h}$. Then, trichloroacetic $(28 \% w / v, 0.5 \mathrm{~mL})$ and thiobarbituric (TBA, $2 \%, w / v$, $0.38 \mathrm{~mL}$ ) acids were added and the mixture was heated at $80{ }^{\circ} \mathrm{C}$ for $20 \mathrm{~min}$. After centrifugation at $3000 \mathrm{~g}$ for $10 \mathrm{~min}$, the malondialdehyde (MDA)-TBA complexes formed in the supernatant were monitored at $532 \mathrm{~nm}$ (Specord 200 spectrophotometer, Analytik Jena, Jena, Germany). The results were given as $\mathrm{IC}_{50}$ values, i.e., extract concentration $(\mathrm{ng} / \mathrm{mL})$ providing $50 \%$ of antioxidant activity.

\subsubsection{Antibacterial activity}

The extracts were tested against microbial strains isolated from different patients hospitalized at the Hospital Center of Trás-os-Montes and Alto Douro (Vila Real, Portugal). Five Gram-negative bacteria (Escherichia coli, Proteus mirabilis, Klebsiella pneumoniae, Pseudomonas aeruginosa and Morganella morganii) and four Gram-positive bacteria (Enterococcus faecalis, Listeria monocytogenes, methicillin-sensitive Staphylococcus aureus (MSSA) and methicillin-resistant Staphylococcus aureus) were incubated at $37{ }^{\circ} \mathrm{C}(24 \mathrm{~h})$ in appropriate fresh medium before further analysis. Minimum inhibitory concentration (MIC) was performed by the microdilution method and the rapid $p$-iodonitrotetrazolium chloride (INT) colorimetric assay, following the methodology previously described by Pires et al. (2018). To each well (96-well microplate) containing a mixture of $190 \mu \mathrm{L}$ of $\mathrm{MHB} / \mathrm{TSB}$ and $10 \mu \mathrm{L}$ of bacteria inoculum (standardized at $1.5 \times 10^{6} \mathrm{CFU} / \mathrm{mL}$ ), $200 \mu \mathrm{L}$ of each diluted extract concentration $(20-0.15 \mathrm{mg} / \mathrm{mL}$ in $5 \%(v / v)$ DMSO/ MHB) were added. The lowest extract concentration that prevented colour change (yellow to pink) by inhibiting bacterial growth is described as MIC. Three negative controls were prepared, one with Mueller-Hinton Broth (MHB), another with the extract, and the third one with medium and antibiotic. For the Gram-negative bacteria, antibiotics, such as ampicillin $(20 \mathrm{mg} / \mathrm{mL})$ and imipenem $(1 \mathrm{mg} / \mathrm{mL})$ were used as positive controls, while ampicillin and vancomycin $(1 \mathrm{mg} / \mathrm{mL})$ were used for the Gram-positive bacteria. The microplates were covered and incubated at $37{ }^{\circ} \mathrm{C}$ for $24 \mathrm{~h}$. MIC was detected adding $40 \mu \mathrm{L}$ 

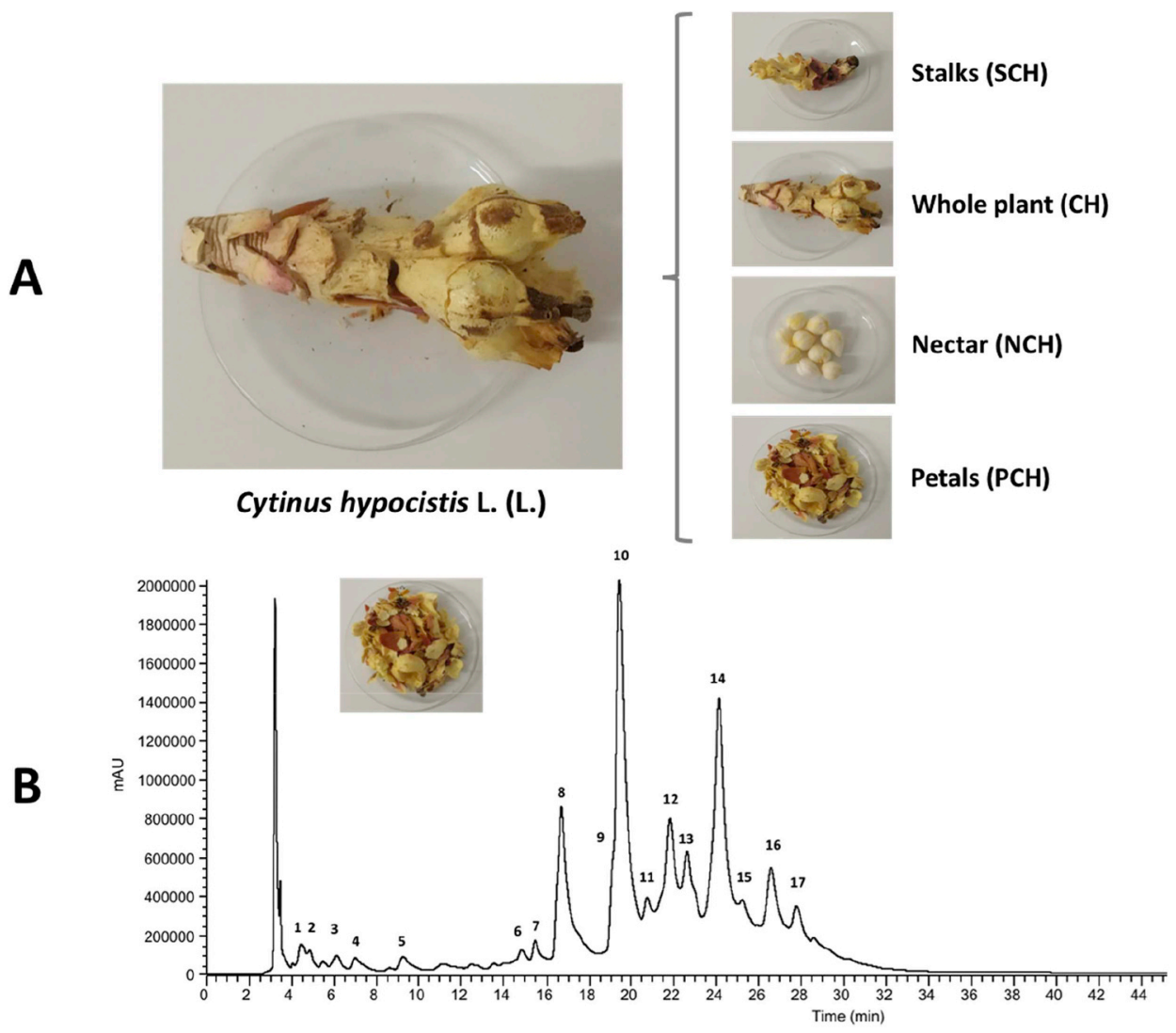

Fig. 1. A: Graphical representation of the four different studied parts of C. hypocistis; and B: Phenolic profile of C. hypocistis petals extract (PCH) recorded at $280 \mathrm{~nm}$.

$(0.2 \mathrm{mg} / \mathrm{mL})$ of $p$-iodonitrotetrazolium chloride (INT) and incubation the mixture at $37{ }^{\circ} \mathrm{C}$ for $30 \mathrm{~min}$. For minimum bactericidal concentration (MBC) determination, $50 \mu \mathrm{L}$ of the different well mixtures (no colour change) were plated on solid medium and incubated at $37{ }^{\circ} \mathrm{C}$ for $24 \mathrm{~h}$. The lowest concentration showing no bacteria growth was defined as MBC.

\subsubsection{Antidiabetic (glucosidase inhibitory) assay}

The $\alpha$-glycosidase inhibitory assay was adapted from the methodology previously described by Les et al. (2017) and Spínola and Castilho (2017). The assay was conducted in a 96-well microplate with a reaction mixture containing $50 \mu \mathrm{L}$ of extract sample diluted in $50 \mu \mathrm{L}$ of $100 \mathrm{mM}$-phosphate buffer ( $\mathrm{pH}$ 6.8) and $50 \mu \mathrm{L}$ yeast $\alpha$-glucosidase (2 $\mathrm{U} / \mathrm{mL}$ in same buffer). The reaction mixture was then incubated for $10 \mathrm{~min}$, followed by addition of $50 \mu \mathrm{L}$ substrate $(5 \mathrm{mM}, p$-nitrophenyl$\alpha$-D-glucopyranoside prepared in the same buffer). After $20 \mathrm{~min}$ of incubation, the release of $p$-nitrophenol was spectrophotometrically measured at $405 \mathrm{~nm}$. Individual blanks and a positive control (acarbose) were prepared. The results were expressed as $\mathrm{IC}_{50}$ values $(\mathrm{mg} /$ $\mathrm{mL}$ ), which were calculated from the inhibition percentage values achieved using the formula: Inhibition $(\%)=\left[\left(\mathrm{Abs}_{\text {control }}-\mathrm{Abs}_{\text {sample }}\right) /\right.$ $\left.\mathrm{Abs}_{\text {control }}\right] \mathrm{x} 100$.

\subsubsection{Tyrosinase inhibitory activity}

Tyrosinase inhibitory activity of the extracts was determined as previously described by Chen et al. (2009), using a SPECTROstar Nano Multi-Detection Microplate Reader and 96-well plates (BMG Labtech, Ortenberg, Germany). Each extract sample was dissolved in a mixture of water and DMSO (5\%). Four wells were attributed to each sample: (A) $120 \mu \mathrm{L}$ of $66 \mathrm{mM}$ PBS (pH 6.8) and $40 \mu \mathrm{L}$ of mushroom tyrosinase in PBS (46 U/mL); (B) $160 \mu \mathrm{L}$ PBS; (C) $80 \mu \mathrm{L}$ PBS, $40 \mu \mathrm{L}$ tyrosinase and $40 \mu \mathrm{L}$ sample; (D) $120 \mu \mathrm{L}$ PBS and $40 \mu \mathrm{L}$ sample extract. After incubation (10 $\mathrm{min}$ at room temperature), $40 \mu \mathrm{L}$ of $2.5 \mathrm{mM}$ L-DOPA dissolved in PBS were added to each well, and the mixtures incubated at room temperature for $20 \mathrm{~min}$. The absorbance of each well was measured at $475 \mathrm{~nm}$, and the inhibition percentage of the tyrosinase activity was calculated using the equation: Inhibition (\%) $=((\mathrm{A}-\mathrm{B})-(\mathrm{C}-\mathrm{D}))$ / $((A-B)) \times 100$. Kojic acid $(0.10 \mathrm{mg} / \mathrm{mL})$ was used as positive control. $\mathrm{IC}_{50}$ values $(\mathrm{mg} / \mathrm{mL})$ were then calculated from the obtained inhibition percentage values.

\subsubsection{Anti-proliferative and hepatotoxic activity}

Cell lines were obtained from ECACC: European Collection of Animal Cell Culture (Salisbury, UK). MCF-7 (breast adenocarcinoma), NCI-H460 (non-small cell lung carcinoma), HeLa (cervical carcinoma) and HepG2 (hepatocellular carcinoma) were the tested human tumour cell lines, and the cell density determination was performed using a sulforhodamine B assay previously described by Guimarães et al. (2013), where the amount of pigmented cells is directly proportional to the total protein mass and, therefore, to the number of bounded cells. These cell lines were treated with different concentrations $(0.125-0.4 \mathrm{mg} / \mathrm{mL})$ of the extract samples dissolved in ultrapure water. For the non-tumour cells, a cell culture previously prepared from a freshly harvested porcine liver obtained from a local slaughter house as described (Guimarães et al., 2013), and named as PLP2, was used to determine hepatotoxicity (Guimarães et al., 2013). A phase-contrast microscope was used to monitor the growth of the cell cultures. The cells were sub-cultured and plated in 96-well plates (density of $1.0 \times 10^{4}$ cells/well). Dulbecco's modified eagle's medium (DMEM) was used, with $10 \%$ of fetal bovine serum (FBS), $100 \mathrm{U} / \mathrm{mL}$ of penicillin, and $100 \mu \mathrm{g} / \mathrm{mL}$ of streptomycin. Ellipticine was used as positive control and the results were expressed as $\mathrm{GI}_{50}$ values (sample concentration in $\mu \mathrm{g} / \mathrm{mL}$ that inhibited $50 \%$ of the net cell growth).

\subsubsection{Anti-inflammatory activity}

The concentration of nitrite produced by lipopolysaccharide (LPS)- 
stimulation was tested in a murine macrophages RAW 264.7 cell line [ECACC: European Collection of Animal Cell Culture (Salisbury, UK)]. Cells were treated with different concentrations $(0.125-0.4 \mathrm{mg} / \mathrm{mL})$ of the extract samples dissolved in ultrapure water, and the production of nitric oxide (NO) was measured using the Griess Reagent System kit Promega (Madison WI, USA) as formerly described by Souilem et al. (2017). Dexamethasone $(50 \mu \mathrm{M})$ was used as a positive control. The results were expressed as $\mathrm{IC}_{50}$ values $(\mu \mathrm{g} / \mathrm{mL})$, corresponding to the extract concentration providing a $50 \%$ inhibition in NO production.

\subsection{Statistical analysis}

Three samples were analyzed and all the assays were carried out in triplicate. The results were expressed as mean values \pm standard deviation (SD). Statistical analysis was conducted with the aid of SPSS v. 23.0 (IBM Corp., Armonk, NY, USA). Data were evaluated by a variance analysis (ANOVA) and by a Tukey's HSD test $(\alpha=0.05)$. The fulfilment of the ANOVA requirements, specifically the normal distribution of residuals and the homogeneity of variance, was tested by means of the Shapiro Wilk's and Levene's tests, respectively. For comparison between two samples, a two-tailed paired Student's $t$-test was applied to assess statistical differences $(\alpha=0.05)$.

\section{Results and discussion}

\subsection{Composition of phenolic compounds}

An exemplary phenolic profile of the $C$. hypocistis petals recorded at $280 \mathrm{~nm}$ is shown in Fig. 1-B, peak characteristics and tentative identities are presented in Table 1 and quantification is present in Table 2. Compounds 1-3 and 5-17 showed a UV spectra coherent with hydrolysable tannins, ant its galloyl and hexahydroxydiphenoyl (HHDP) derivatives. According to the literature, the main characteristics in the mass spectra of these compounds are the losses of a proton $[\mathrm{M}-\mathrm{H}]^{-}$, one or more ellagic acid (302 $\mathrm{mu})$, gallic acid $(170 \mathrm{mu})$, and/or galloyl groups (152 mu) (Carocho et al., 2014). Compounds number 1 and 2 were tentatively identified as galloyl-glucose and digalloyl-glucose, respectively, due to the loss of a galloyl moiety characterized by a typical $\mathrm{MS}^{2}$ fragment at $\mathrm{m} / \mathrm{z} 331$. Elimination of a glucose moiety [162 $\mathrm{mu}$ ] and subsequently formation of a deprotonated gallic acid at $\mathrm{m} / \mathrm{z}$ 169 were also observed. The deprotonated gallic acid underwent decarboxylation with mass loss of 44 to form a trihydroxyphenol moiety at $m / z 125$ (Tan et al., 2011). Compounds number 3 and 5 were tentatively deduced as trigalloyl-glucose, with $[\mathrm{M}-\mathrm{H}]^{-}$at $m / z$ 635, and a typical $\mathrm{MS}^{2}$ fragment at $\mathrm{m} / \mathrm{z} 483$, indicating the loss of one galloyl group (152 mu). Product ions at $m / z 465$ and 313, usually found on the fragmentation scheme of gallotannins, were also observed (Mena et al., 2012; Tan et al., 2011). Compound number 6 ([M-H $]^{-}$at $\mathrm{m} / z$ 937; fragment ions at $m / z 767,637,467$ and 301 ) was coherent with trigalloyl-HHDP-glucose isomers (Carocho et al., 2014). Compound number 7 (tetragalloyl-glucoside; $m / z$ 787) presented a characteristic $\mathrm{MS}^{2}$ fragment at $m / z 635$ (trigalloyl-glucose), correspondent to the loss of one galloyl group ( $152 \mathrm{mu}$ ), and product ions at $\mathrm{m} / z$ of 617 and 465, consistent with the loss of a $m / z 170$ gallate moiety, $\mathrm{H}_{2} \mathrm{O} \mathrm{m} / z 18$ and galloyl $m / z$ 152, respectively (Owen et al., 2003). Compound number 8 presented a singly-charged pseudo-molecular ion $[\mathrm{M}-\mathrm{H}]^{-}$at $\mathrm{m} / \mathrm{z} 783$ and together with daughter ions at $m / z$ 765, 597, and 301 allowed its identification as pedunculagin (i.e., bis-HHDP-glucose) isomers (Calani et al., 2013; Sentandreu et al., 2013). The UV spectra of Compound number 9 shows a precursor ion at $m / z 939$ and product ions at $m / z 787$ and 769 , attributed to the loss of a galloyl group [M - $152-\mathrm{H}]^{-}$and a water molecule $\left[\mathrm{M}-152-18-\mathrm{H}^{-}\right.$, respectively. This ion fragment $(\mathrm{m} / \mathrm{z}$ 769 ) underwent then the loss of a galloyl and a water molecule, originating $m / z$ fragments of 617 and 599 , respectively. Although with the absence of two $\mathrm{MS}^{2}$ fragments $(\mathrm{m} / \mathrm{z}$ at 617 and 599) present in the UV spectra of compound number 9, compound number 11 was also

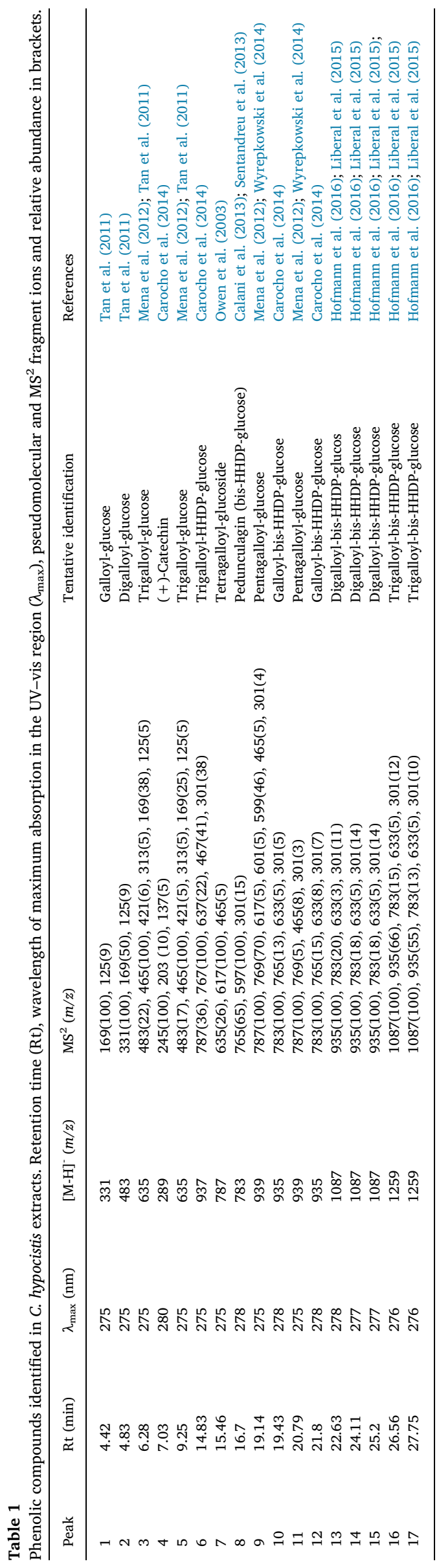


Table 2

Phenolic compounds quantification in C. hypocistis extracts.

\begin{tabular}{|c|c|c|c|c|c|}
\hline \multirow[t]{2}{*}{ Peak } & \multirow[t]{2}{*}{ Tentative identification } & \multicolumn{4}{|c|}{ Content (mg/g extract) } \\
\hline & & $\mathrm{CH}$ & $\mathrm{PCH}$ & $\mathrm{SCH}$ & $\mathrm{NCH}$ \\
\hline 1 & Galloyl-glucose ${ }^{1}$ & $0.81 \pm 0.01^{\mathrm{c}}$ & $1.9 \pm 0.05^{\mathrm{a}}$ & $1.19 \pm 0.08^{\mathrm{b}}$ & $0.77 \pm 0.05^{\mathrm{c}}$ \\
\hline 2 & Digalloyl-glucose $^{1}$ & $0.99 \pm 0.01^{\mathrm{b}}$ & $1.68 \pm 0.03^{\mathrm{a}}$ & $0.335 \pm 0.004^{\mathrm{d}}$ & $0.65 \pm 0.02^{\mathrm{c}}$ \\
\hline 3 & Trigalloyl-glucose $^{1}$ & $1.47 \pm 0.04^{\mathrm{a}}$ & $0.46 \pm 0.04^{\mathrm{b}}$ & $1.49 \pm 0.07^{\mathrm{a}}$ & $0.146 \pm 0.003^{c}$ \\
\hline 4 & $(+)$-Catechin ${ }^{2}$ & $1.83 \pm 0.04^{\mathrm{c}}$ & $2.9 \pm 0.1^{\mathrm{a}}$ & $2.17 \pm 0.06^{\mathrm{b}}$ & $1.69 \pm 0.03^{\mathrm{d}}$ \\
\hline 5 & Trigalloyl-glucose ${ }^{1}$ & $1.09 \pm 0.03^{\mathrm{b}}$ & $1.41 \pm 0.06^{\mathrm{a}}$ & $0.64 \pm 0.03^{\mathrm{c}}$ & $\operatorname{tr}$ \\
\hline 6 & Trigalloyl-HHDP-glucose ${ }^{1}$ & $1.26 \pm 0.04^{\mathrm{c}}$ & $1.88 \pm 0.03^{\mathrm{b}}$ & $2.52 \pm 0.08^{\mathrm{a}}$ & $0.29 \pm 0.01^{\mathrm{d}}$ \\
\hline 7 & Tetragalloyl-glucoside ${ }^{1}$ & $1.907 \pm 0.004^{\mathrm{b}}$ & $1.13 \pm 0.02^{\mathrm{c}}$ & $2.7 \pm 0.1^{\mathrm{a}}$ & $0.114 \pm 0.005^{\mathrm{d}}$ \\
\hline 8 & Pedunculagin (bis-HHDP-glucose) ${ }^{3}$ & $2.23 \pm 0.03^{\mathrm{b}}$ & $3.34 \pm 0.05^{\mathrm{a}}$ & $1.63 \pm 0.04^{\mathrm{c}}$ & $\operatorname{tr}$ \\
\hline 9 & Pentagalloyl-glucose $\mathrm{e}^{1}$ & $5.10 \pm 0.04^{\mathrm{a}}$ & $5.3 \pm 0.2^{\mathrm{a}}$ & $3.7 \pm 0.2^{\mathrm{b}}$ & $1.43 \pm 0.06^{\mathrm{c}}$ \\
\hline 10 & Galloyl-bis-HHDP-glucose ${ }^{3}$ & $42 \pm 1^{\mathrm{a}}$ & $41 \pm 1^{\mathrm{a}}$ & $34 \pm 1^{\mathrm{b}}$ & $5.43 \pm 0.05^{\mathrm{c}}$ \\
\hline 11 & Pentagalloyl-glucose ${ }^{1}$ & $0.85 \pm 0.03^{\mathrm{b}}$ & $2.80 \pm 0.01^{\mathrm{a}}$ & $0.14 \pm 0.01^{\mathrm{c}}$ & $0.114 \pm 0.004^{c}$ \\
\hline 12 & Galloyl-bis-HHDP-glucose ${ }^{3}$ & $9.60 \pm 0.05^{\mathrm{b}}$ & $11.1 \pm 0.3^{\mathrm{a}}$ & $6.8 \pm 0.3^{\mathrm{c}}$ & $2.1 \pm 0.1^{\mathrm{d}}$ \\
\hline 13 & Digalloyl-bis-HHDP-glucos ${ }^{3}$ & $6.45 \pm 0.01^{\mathrm{a}}$ & $6.5 \pm 0.2^{\mathrm{a}}$ & $5.1 \pm 0.1^{\mathrm{b}}$ & $1.74 \pm 0.02^{\mathrm{c}}$ \\
\hline 14 & Digalloyl-bis-HHDP-glucose ${ }^{3}$ & $18.3 \pm 0.4^{\mathrm{b}}$ & $27.2 \pm 0.1^{\mathrm{a}}$ & $11.4 \pm 0.2^{\mathrm{c}}$ & $3.64 \pm 0.02^{\mathrm{d}}$ \\
\hline 15 & Digalloyl-bis-HHDP-glucose ${ }^{3}$ & $5.4 \pm 0.1^{\mathrm{b}}$ & $7.7 \pm 0.1^{\mathrm{a}}$ & $1.65 \pm 0.02^{\mathrm{c}}$ & $1.78 \pm 0.02^{\mathrm{c}}$ \\
\hline 16 & Trigalloyl-bis-HHDP-glucose ${ }^{3}$ & $2.58 \pm 0.02^{\mathrm{c}}$ & $13.1 \pm 0.7^{\mathrm{a}}$ & $4.2 \pm 0.1^{\mathrm{b}}$ & $1.30 \pm 0.01^{\mathrm{d}}$ \\
\hline \multirow[t]{2}{*}{17} & Trigalloyl-bis-HHDP-glucose ${ }^{3}$ & nd & $7.4 \pm 0.3^{*}$ & $2.35 \pm 0.01^{*}$ & nd \\
\hline & $\Sigma$ Phenolic compounds & $102.0 \pm 0.6^{\mathrm{b}}$ & $137 \pm 2^{\mathrm{a}}$ & $82 \pm 2^{\mathrm{c}}$ & $21.2 \pm 0.2^{\mathrm{d}}$ \\
\hline
\end{tabular}

CH: whole plant extract; PCH: petals extract; SCH: stalks extract; NCH: nectar extract. Standard calibration curves recorded at $280 \mathrm{~nm}$ : $\left({ }^{1}\right)-\mathrm{Gallic}$ acid $\left(\mathrm{y}=131538 \mathrm{x}+292163 ; \mathrm{R}^{2}=0.9998 ; \mathrm{LOD}=0.68 \mu \mathrm{g} / \mathrm{mL} ; \mathrm{LOQ}=1.61 \mu \mathrm{g} / \mathrm{mL}\right) ;\left({ }^{2}\right)-$ catechin $\left(\mathrm{y}=84950 \mathrm{x}+23200 ; \mathrm{R}^{2}=0.9999 ; \mathrm{LOD}=0.17 \mu \mathrm{g} / \mathrm{mL} ;\right.$ $\mathrm{LOQ}=0.68 \mu \mathrm{g} / \mathrm{mL}) ;\left({ }^{3}\right)$ - Ellagic acid $\left(\mathrm{y}=26719 \mathrm{x}-317255 ; \mathrm{R}^{2}=0.9996 ; \mathrm{LOD}=0.10 \mu \mathrm{g} / \mathrm{mL} ; \mathrm{LOQ}=0.48 \mu \mathrm{g} / \mathrm{mL}\right.$ ). In each row, different letters correspond to significant differences $(p<0.05)$ between samples. "Means statistical differences obtained by a $t$-student test.

identified as pentagalloyl-glucose $(\mathrm{m} / \mathrm{z} 939)$ due to characteristic product ions at $m / z 787,769$, and 465 , which unveil the presence of homologous series of galloylglucose (Mena et al., 2012; Wyrepkowski et al., 2014). Compound number 10 and $12\left([\mathrm{M}-\mathrm{H}]^{-}\right.$at $m / z$ 935) presented the same pseudomolecular ion and $\mathrm{MS}^{2}$ product ions at $m / z 783$, 765,633 , and 301, likely due to the loss of a water molecule, HHDP, and galloyl-glucose moieties, respectively, thus being consistent with galloyl-bis-HHDP-glucose isomers (Carocho et al., 2014). The fragment ions at $m / z 1087,935$, and 783 present in the UV spectra of compounds number 13-17, show the consecutive loss of two galloyl moieties; that, together with pseudomolecular ions at 1087 and $1259 \mathrm{~m} / \mathrm{z}$ allowed its identification as digalloyl-bis-HHDP-glucopyranose and trigalloyl-bisHHDP-glucopyranose (Hofmann et al., 2016; Liberal et al., 2015; Salminen et al., 1999).

Regarding falvan-3-ols, $(+)$-catechin (compound number 4: $[\mathrm{M}-\mathrm{H}]^{-}$ at $m / z 289$ ) was the only detected compound, being identified based on the characteristic $\mathrm{MS}^{2}$ fragments at $\mathrm{m} / \mathrm{z} 245$ (loss of $\mathrm{CO}_{2}$ ), and 203 (cleavage of the A-ring of flavan-3-ol) (Carocho et al., 2014).

Although at different concentrations, seventeen phenolic compounds were identified in all the four studied samples, being $\mathrm{PCH}$ the sample exhibiting higher concentrations of compounds, followed by $\mathrm{CH}$, being galloyl-bis-HHDP-glucose the main compound in all the samples. NCH was the sample with the lowest levels of phenolic compounds (Table 2).

The most prevalent biological and pharmacological properties reported for tannins on a molecular basis are superoxide anion scavenging, apoptosis, antitumor, anti-EVB, anti-MRSA, and anti-plasmin inhibition, which are attributed to its strong capacity to bind to proteins, large molecular compounds, and metallic ions. Galloyl moieties have been identified as the most bioactive components of tannin-rich plants, playing multiple functional roles such as antimicrobial, anti-inflammatory, antidiabetic, and antioxidant activities (Maisetta et al., 2019). Besides, its excellent antioxidant capacity is associated with chelation potency, which is mainly attributed to its catechol or galloyl moieties present on the B ring of its structure (Okuda and Ito, 2011). Moreover, its tyrosinase inhibition properties have been largely attributed to their competitive inhibition of monophenolase and strong copper chelation activity (Niu and Aisa, 2017).

\subsection{Antioxidant activity}

Free radicals and other oxidants have played central role in the pathophysiology of various diseases through several mechanisms, being lipid peroxidation one of the most extensively used research model for identification of natural antioxidants (Lü et al., 2010). This process is initiated when any free radical attacks and abstracts a reactive hydrogen atom from a methylene group in an unsaturated fatty acid, which results in the formation of a carbon-centred lipid radical. The lipid radical can then react with molecular oxygen to form a lipid peroxyl radical that later undergoes rearrangement to form malondialdehyde (MDA) and 4-hydroxynonenal (4-HNA) (Phaniendra et al., 2015). These toxic end-products cause damage to DNA, membrane proteins, enzymes, and receptors, among others, which can lead to cell lysis or exacerbate the activity of various cascades implicated in degenerative diseases and cancer (Phaniendra et al., 2015). Lipid peroxyl radicals can also further propagate the peroxidation process by abstracting hydrogen atoms from the other lipid molecules. In a dosedependent manner, both methods, OxHLIA and TBARS, allowed the evaluation of the antioxidant effect of the studied hydroethanolic extracts $(\mathrm{CH}, \mathrm{PCH}, \mathrm{SCH}$, and $\mathrm{NCH})$ and; although through different mechanisms, both are equally a consequence of lipid peroxidation. OxHLIA establishes the time and concentration at which antioxidants can retard haemolysis by capturing the hydrophilic and/or lipophilic radicals, and TBARS the concentration at which the extracts can prevent the formation of MDA through the donation of hydrogen atoms to the lipid peroxyl radical species. The obtained results for both assays are displayed in Table 3. All the four tested extracts showed high bioactivity, on the order of nanograms per millilitre, and lower $\mathrm{IC}_{50}$ than the tested positive control, trolox, a water-soluble analogue of vitamin E. Concerning OxHLIA assay, all the $\mathrm{IC}_{50}$ values of the tested extracts were approximately 30 up to 73 times lower, and for TBARS approximately 9 up to 16 times inferior to trolox. The lowest $\mathrm{IC}_{50}$, for both assays, was obtained by the petals extract (OxHLIA: $279 \mathrm{ng} / \mathrm{mL}$ ( $\Delta t=60 \mathrm{~min})$ and $384 \mathrm{ng} / \mathrm{mL}(\Delta t=120 \mathrm{~min})$; TBARS: $342 \mathrm{ng} / \mathrm{mL})$. There is certain agreement that complete based hydrogen atoms transfer assays (HAT) include among others, 1,1-diphenyl-2-picrylhydrazyl radical (DPPH*) and OxHLIA assays. In a 2019 study performed by Maisetta and colleagues, $C$. hypocistis whole plant ethanolic extracts displayed strong antioxidant activity, DPPH: $6.8 \pm 1.2 \mu \mathrm{g} / \mathrm{mL}$ 
Table 3

Antioxidant activity of $C$. hypocistis extracts and positive control measured by the cell-based assays of OxHLIA and TBARS.

\begin{tabular}{llll}
\hline & \multicolumn{2}{l}{ OxHLIA $\left(\mathrm{IC}_{50}, \mathrm{ng} / \mathrm{mL}\right)$} & TBARS $\left(\mathrm{IC}_{50}, \mathrm{ng} / \mathrm{mL}\right)$ \\
\cline { 2 - 4 } & $\Delta t=60 \mathrm{~min}$ & $\Delta t=120 \mathrm{~min}$ & \\
\hline $\mathrm{CH}$ & $285 \pm 4^{\mathrm{b}, \mathrm{c}}$ & $406 \pm 5^{\mathrm{c}}$ & $413 \pm 9^{\mathrm{c}}$ \\
PCH & $279 \pm 5^{\mathrm{c}, \mathrm{d}}$ & $384 \pm 9^{\mathrm{c}}$ & $342 \pm 2^{\mathrm{d}}$ \\
SCH & $306 \pm 2^{\mathrm{b}}$ & $458 \pm 4^{\mathrm{b}}$ & $634 \pm 12^{\mathrm{a}}$ \\
NCH & $672 \pm 15^{\mathrm{a}}$ & $1032 \pm 28^{\mathrm{a}}$ & $551 \pm 13^{\mathrm{b}}$ \\
Trolox & $20384 \pm 363$ & $44212 \pm 1500$ & $5389 \pm 320$
\end{tabular}

$\mathrm{CH}$ : whole plant extract; PCH: petals extract; SCH: stalks extract; NCH: nectar extract. The results are presented as mean \pm standard deviation and expressed as $\mathrm{IC}_{50}$ values, which correspond to the extract concentration in $\mathrm{ng} / \mathrm{mL}$ required to protect $50 \%$ of the erythrocyte population from haemolysis for $\Delta t$ of $60 \mathrm{~min}$ and 120 min or to provide $50 \%$ of antioxidant activity in the OxHLIA and TBARS assays, respectively. In each column, different letters correspond to significant differences $(p<0.05)$ between samples. *Trolox differs significantly from the plant extracts $(p<0.05)$.

(Maisetta et al., 2019). Although both studies utilised HAT in vitro methods, the present study assay considered the level of oxidative stress in a biological sample, with biological fluids and cell components present during the analysis. Despite these potential external interferences, when compared, the ability of $\mathrm{CH}$ extracts to quench free radicals by hydrogen donation was higher for the present study, 24-fold more effective.

\subsection{Antibacterial activity}

In recent years, antibiotic resistance has become an alarming issue, which increased the interest on plant-derived compounds discovery as new active antibacterial agents (Stojković et al., 2013). The four hydroethanolic extracts $(\mathrm{CH}, \mathrm{PCH}, \mathrm{SCH}$ and $\mathrm{NCH})$ of $\mathrm{C}$. hypocistis were evaluated for their antibacterial potential against multi-resistant pathogenic strains (Table 4), such as Gram-positive (E. feacalis, L. monocytogenes, and MRSA) and Gram-negative bacteria (E. coli, P. mirabilis, $K$. pneumoniae, $P$. aeruginosa, and $M$. morganii). Ampicillin is a betalactamic antibiotic widely used for its ability to destroy Gram-positive and Gram-negative bacteria (Rozas et al., 2010). Compared to this antibiotic, all the four $C$. hypocistis tested extracts were more effective against three Gram-negative bacteria. Considering K. pneumoniae, the extracts were 2 to 8 -fold more effective than ampicillin. For $P$. aeruginosa and M. morganii, 8 to 16 -fold more effective than ampicillin. MBC values were not obtained for any of the tested extracts (values > $20 \mathrm{mg} / \mathrm{mL}$ ). The MIC values shown in Table 4 indicate that the extracts were active against both Gram-negative and Gram-positive bacteria, being the first more sensitive to all the plant extracts. In general, the hydroethanolic extracts from the stalks were the most ( $\mathrm{SCH}$ MIC $=0.625-2.5 \mathrm{mg} / \mathrm{mL}$ ) and the nectar the least $(\mathrm{NCH}$ MIC $=2.5-10 \mathrm{mg} / \mathrm{mL}$ ) effective to inhibit both Gram-positive and Gram-negative bacteria growth. For three tested microorganisms (MRSA, K. pneumoniae, and P. aeruginosa), C. hypocistis ethanolic extracts displayed better MICs in a recent study (Maisetta et al., 2019). This could be due to the use of clinical isolates in the present study, which might exhibit a higher resistance profile when compared with the ATCC strains tested by Maisetta and co-workers. Although both studies tested the capacity of the extracts to inhibit bacterial growth, the plant material from the other study was previously resuspended in cyclohexane, the collected supernatant lyophilised, and later subjected to a second extraction with ethanol. The pre-extraction step reported by Maisetta et al. (2019) might also be accountable for the obtained MIC values due to a higher concentration of extracted polar compounds (Maisetta et al., 2019). Previous studies investigating the antimicrobial activity of tannin-rich plant extracts have attributed the microbial growth inhibition to their content in gallotannins and related compounds, which mainly act on the membranes of the bacteria and/or their ability to complex metal ions (Maisetta et al., 2019). Several studies have also shown that Gram-negative bacteria are more resistant to plant derived biomolecules due to the strong repulsive negative charge of its lipopolysaccharides (Maisetta et al., 2019). Contrarily, in the present work, the extracts were more effective inhibiting Gramnegative bacteria, and as such, the studied extract could become a source to the discovery of novel antimicrobial agents.

\subsection{Antidiabetic activity}

$\alpha$-Glucosidase inhibitors fall under the third category of oral hypoglycemic agents. They cleave glyosidic bonds in complex carbohydrates to release absorbable monosaccharides; thus, $\alpha$-glucosidase inhibitors display useful anti-hyperglycaemic effects and can be an important strategy in the management of hyperglycaemia linked to type 2 diabetes (Leroux-Stewart et al., 2015). Only a few $\alpha$-glucosidase inhibitors are commercially available, and all of them involve tedious multi-step procedures. Additionally, clinically they have been associated with serious gastrointestinal side effects (Leroux-Stewart et al., 2015). Therefore, the discovery of potent non-sugar based $\alpha$-glucosidase inhibitors from natural sources have been receiving tremendous attention, due to the highly abundant compounds in nature and their promising biological activities (Yin et al., 2014). The $\alpha$-glucosidase inhibitor effectiveness of the different extracts (Table 5) was expressed on the basis of resulting $\mathrm{IC}_{50}$ values. $\mathrm{SCH}$ was the best extract $(0.039 \mathrm{mg} / \mathrm{mL})$, followed by CH $(0.040 \mathrm{mg} / \mathrm{mL}), \mathrm{PCH}(0.046 \mathrm{mg} / \mathrm{mL})$, and $\mathrm{NCH}(0.214 \mathrm{mg} / \mathrm{mL})$. The SCH $\mathrm{IC}_{50}$ was approximately 21 times lower than the positive control acarbose. For PCH and $\mathrm{CH}$, the $\mathrm{IC}_{50}$ values were approximately 20 and 18 times lower, respectively. The

Table 4

Antibacterial activity of $C$. hypocistis extracts and positive controls.

\begin{tabular}{|c|c|c|c|c|c|c|c|c|c|c|c|c|c|c|}
\hline & \multicolumn{2}{|l|}{$\mathrm{CH}$} & \multicolumn{2}{|l|}{$\mathrm{PCH}$} & \multicolumn{2}{|l|}{$\mathrm{SCH}$} & \multicolumn{2}{|l|}{$\mathrm{NCH}$} & \multicolumn{2}{|c|}{ Ampicillin } & \multicolumn{2}{|l|}{ Imipenem } & \multicolumn{2}{|c|}{ Vancomycin } \\
\hline & MIC & MBC & MIC & MBC & MIC & MBC & MIC & MBC & MIC & MBC & MIC & MBC & MIC & MBC \\
\hline \multicolumn{15}{|l|}{ Gram-negative bacteria } \\
\hline Escherichia coli & 1.25 & $>20$ & 1.25 & $>20$ & 0.625 & $>20$ & 2.5 & $>20$ & $<0.15$ & $<0.15$ & $<0.0078$ & $<0.0078$ & n.t. & n.t. \\
\hline Klebsiella pneumoniae & 1.25 & $>20$ & 1.25 & $>20$ & 1.25 & $>20$ & 5 & $>20$ & 10 & 20 & $<0.0078$ & $<0.0078$ & n.t. & n.t. \\
\hline Morganella morganii & 1.25 & $>20$ & 2.5 & $>20$ & 1.25 & $>20$ & 2.5 & 20 & 20 & $>20$ & $<0.0078$ & $<0.0078$ & n.t. & n.t. \\
\hline Proteus mirabilis & 1.25 & 20 & 1.25 & 20 & 1.25 & 20 & 5 & $>20$ & $<015$ & $<0.15$ & $<0.0078$ & $<0.0078$ & n.t. & n.t. \\
\hline Pseudomonas aeruginosa & 2.5 & $>20$ & 2.5 & $>20$ & 1.25 & $>20$ & 2.5 & $>20$ & $>20$ & $>20$ & 0.5 & 1 & n.t. & n.t. \\
\hline \multicolumn{15}{|l|}{ Gram-positive bacteria } \\
\hline Enterococcus faecalis & 2.5 & 20 & 2.5 & $>20$ & 2.5 & $>20$ & 5 & $>20$ & $<0.15$ & $<0.15$ & n.t. & n.t. & $<0.0078$ & $<0.0078$ \\
\hline Listeria monocytogenes & 2.5 & $>20$ & 2.5 & $>20$ & 2.5 & $>20$ & 10 & $>20$ & $<0.15$ & $<0.15$ & $<0.0078$ & $<0.0078$ & n.t. & n.t. \\
\hline MRSA & 1.25 & $>20$ & 1.25 & $>20$ & 0.625 & $>20$ & 2.5 & $>20$ & $<0.15$ & $<0.15$ & n.t. & n.t. & 0.25 & 0.5 \\
\hline
\end{tabular}

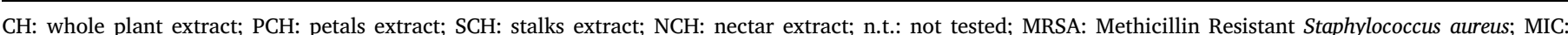
Minimum inhibitory concentration in $\mathrm{mg} / \mathrm{mL}$; MBC: Minimum bactericidal concentration in $\mathrm{mg} / \mathrm{mL}$. 
Table 5

Enzyme inhibitory, anti-proliferative, hepatotoxic, and anti-inflammatory properties of $C$. hypocistis extracts and positive controls.

\begin{tabular}{|c|c|c|c|c|c|}
\hline & $\mathrm{CH}$ & $\mathrm{PCH}$ & $\mathrm{SCH}$ & $\mathrm{NCH}$ & Positive control \\
\hline \multirow[b]{2}{*}{$\alpha$-Glucosidase } & \multicolumn{4}{|c|}{ Antidiabetic activity $\left(\mathrm{IC}_{50}, \mathrm{mg} / \mathrm{mL}\right)$} & Acarbose \\
\hline & $0.040 \pm 0.001^{\mathrm{c}}$ & $0.046 \pm 0.004^{\mathrm{c}}$ & $0.039 \pm 0.001^{\mathrm{c}}$ & $0.214 \pm 0.005^{\mathrm{b}}$ & $0.83 \pm 0.02^{\mathrm{a}}$ \\
\hline & Tyrosinase inhib & $\left(\mathrm{IC}_{50}, \mathrm{mg} / \mathrm{mL}\right)$ & & & Kojic acid \\
\hline \multirow[t]{2}{*}{ Tyrosinase } & $0.20 \pm 0.01^{\mathrm{a}}$ & $0.19 \pm 0.01^{\mathrm{b}}$ & $0.09 \pm 0.02^{\mathrm{c}}$ & $27.6 \pm 0.7 \% *$ & $0.078 \pm 0.001^{\mathrm{d}}$ \\
\hline & \multicolumn{4}{|c|}{ Cytotoxic activity $\left(\mathrm{GI}_{50}, \mu \mathrm{g} / \mathrm{mL}\right)$} & Ellipticine ${ }^{* *}$ \\
\hline HeLa & $80 \pm 7^{b}$ & $71 \pm 2^{b}$ & $68 \pm 4^{b}$ & $159 \pm 5^{a}$ & $1.91 \pm 0.06$ \\
\hline NCI-H460 & $102 \pm 4^{b}$ & $93 \pm 8^{b}$ & $100 \pm 6^{b}$ & $175 \pm 13^{\mathrm{a}}$ & $1.03 \pm 0.09$ \\
\hline MCF-7 & $117 \pm 6^{\mathrm{b}}$ & $103 \pm 7^{b}$ & $98 \pm 4^{\mathrm{b}}$ & $206 \pm 11^{\mathrm{a}}$ & $1.1 \pm 0.2$ \\
\hline HepG2 & $80 \pm 2^{\mathrm{b}, \mathrm{c}}$ & $90 \pm 6^{b}$ & $77 \pm 2^{c}$ & $110 \pm 3^{\mathrm{a}}$ & $1.1 \pm 0.2$ \\
\hline \multirow[t]{2}{*}{ PLP2 } & $>400$ & $>400$ & $>400$ & $>400$ & $3.2 \pm 0.7$ \\
\hline & \multicolumn{4}{|c|}{ Anti-inflammatory activity $\left(\mathrm{IC}_{50}, \mu \mathrm{g} / \mathrm{mL}\right)$} & Dexamethasone** \\
\hline RAW 264.7 & $136 \pm 11^{\mathrm{b}}$ & $127 \pm 8^{c}$ & $127 \pm 12^{c}$ & $277 \pm 14^{\mathrm{a}}$ & $16 \pm 1$ \\
\hline
\end{tabular}

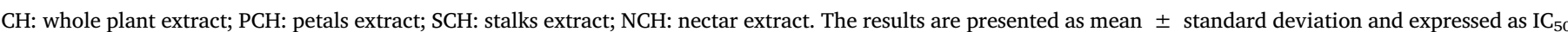

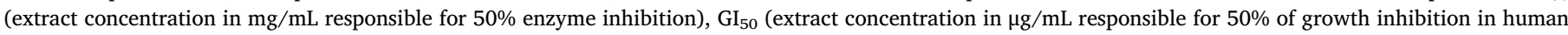

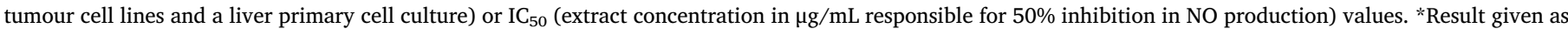

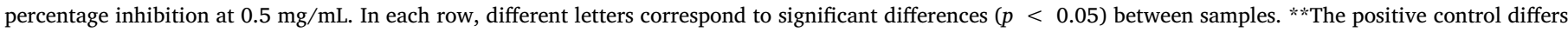
significantly from the plant extracts $(p<0.05)$

nectar extract presented a biggest $\mathrm{IC}_{50}$ value, approximately 2.6 times higher than acarbose. To the authors' best knowledge, this is the first report evaluating the anti- $\alpha$-glucosidase activity of $C$. hypocistis extracts; therefore, no comparisons could be performed.

\subsection{Anti-tyrosinase activity}

Tyrosinase is widely distributed in microorganisms, animals, and plants. This binuclear copper centre enzyme catalyses two distinct reactions: the hydroxylation of tyrosine by monophenolase action and the oxidation of 3,4-dihydroxyphenylalanine (L-DOPA) to $o$-dopaquinone through diphenolase action. Sequentially, dopaquinone can be readily converted to dopachrome, an orange to red pigment (Kim and Uyama, 2005). Tyrosinase catalyses the oxidation of phenolic compounds to the corresponding quinones and is responsible for the enzymatic browning of fruits and vegetables, which display a characteristic undesirable colour and flavour. The oxidation products of phenolic compounds can then react with other food components, including amines, peptides, and proteins, which further reduces food quality and digestibility (Shao et al., 2018). Tyrosinase also plays a critical role in the biosynthesis of melanin and its over-activity can cause skin hyperpigmentation (Niu and Aisa, 2017). Products containing ingredients such as hydroquinone, kojic acid, and retinoids have been utilised in the past to suppress the severity of hyperpigmentation; however, long term exposure to them have been reported to present cytotoxic, irritating, and mutagenic effects on the skin (Draelos, 2007). Therefore, the discovery of novel high-performance tyrosinase inhibitors is in great need for the food and cosmetic field.

Tyrosinase inhibition was determined using purified enzyme from mushroom and expressed on the basis of resulting $\mathrm{IC}_{50}$ values presented on Table 5. To the authors' best knowledge, this is the second study reporting a quantitative analysis of $C$. hypocistis anti-tyrosinase activity (Maisetta et al., 2019). Although to different extents, all C. hypocistis ethanolic extracts were able to inhibit tyrosinase activity, being the stalks the best result (SCH: $0.09 \mathrm{mg} / \mathrm{mL}$ ), followed by the petals (PCH: $0.19 \mathrm{mg} / \mathrm{mL}$ ), whole plant $(\mathrm{CH}: 0.20 \mathrm{mg} / \mathrm{mL}$ ), and nectar (NCH: $27.6 \%)$. For the maximum tested concentration $(0.5 \mathrm{mg} / \mathrm{mL}), \mathrm{NCH}$ was only able to inhibit $27.6 \%$ of tyrosinase. SCH was the extract exhibiting the closest $\mathrm{IC}_{50}(0.09 \mathrm{mg} / \mathrm{mL})$ value comparing to the positive control, kojic acid $(0.078 \mathrm{mg} / \mathrm{mL})$, one of the most intensively studied tyrosinase inhibitors (Draelos, 2007). C. hypocistis whole plant displayed a better $\mathrm{IC}_{50}(0.0098 \mathrm{mg} / \mathrm{mL})$ in a 2019 study (Maisetta et al., 2019). Similarly, to the antibacterial activity, this could be due to the pre-extraction step performed by Maisetta and colleagues and therefore, the presence of a higher concentration of bioactive compounds.

\subsection{Anti-proliferative and hepatotoxic activity}

Plant-derived products garner increasing attention in cancer chemotherapy, aside from view as more biologically friendly, and consequently more co-evolved with their target sites, there is also evidence that natural product-derived anticancer drugs have alternative modes of promoting cell death (Gali-Muhtasib et al., 2015; Khalid et al., 2016). C. hypocistis hydroethanolic extracts were screened for their cytotoxic activity using different tumour cell lines. The sulforhodamine B colorimetric assay was applied in order to determine the inhibitory growth activity of the tested extracts for four human tumour cell lines: NCI-H460 (non-small cell lung cancer), HeLa (cervical carcinoma), HepG2 (hepatocellular carcinoma), and MCF-7 (breast carcinoma). The results (Table 5) are expressed as $\mathrm{GI}_{50}$, which represents the $C$. hypocistis extracts concentrations required to inhibit $50 \%$ of cell growth. The values were in general lower (high activity), showing a significant dosedependent cytotoxic effect. In absolute terms, the cell line HepG2 was the most susceptible to $C$. hypocistis extracts, followed by HeLa, NCI-H460, and MCF-7. HeLa $\left(\mathrm{GI}_{50}=68 \mu \mathrm{g} / \mathrm{mL}\right)$ was the most vulnerable cell line to $C$. hypocistis extracts action, namely $\mathrm{SCH}$. C. hypocistis nectar $(\mathrm{NCH})$ showed the least effective results. When comparing its $\mathrm{GI}_{50}$, the values were 1.44-2.35-fold higher than the optimal value for the different tested cell lines: HeLa (NCH: $159 \mu \mathrm{g} / \mathrm{mL}$ versus SCH: $68 \mu \mathrm{g} / \mathrm{mL}$ ), NCI-H46 (NCH: $175 \mu \mathrm{g} / \mathrm{mL}$ versus PCH: $93 \mu \mathrm{g} / \mathrm{mL}$ ), MCF-7 (NCH: $206 \mu \mathrm{g} / \mathrm{mL}$ versus SCH: $98 \mu \mathrm{g} / \mathrm{mL}$ ), and HepG2 (NCH: $110 \mu \mathrm{g} /$ $\mathrm{mL}$ versus SCH: $77 \mu \mathrm{g} / \mathrm{mL}$ ). From all the four C. hypocistis extracts tested ( $\mathrm{CH}, \mathrm{PCH}, \mathrm{SCH}$ and $\mathrm{NCH}$ ), the stalks extract ( $\mathrm{SCH}$ ) exhibited the best $\mathrm{GI}_{50}$ values for three cell lines (HeLa, MCF-7, and HepG2). Although the petals extract $(\mathrm{PCH})$ presented a better $\mathrm{GI}_{50}$ for one of the tested cell lines, NCI-H460, the value was really similar when compared with SCH, $93 \mu \mathrm{g} / \mathrm{mL}$ versus $100 \mu \mathrm{g} / \mathrm{mL}$.

To the authors' best knowledge, there are only two studies on the cytotoxic activity of $C$. hypocistis extracts (Magiatis et al., 2001; Zucca et al., 2015). The data from the present study are in accordance with 
that reported by Magiatis and colleagues, who found that the methanolic extracts of three Greek Cytinus taxa exhibited cytotoxic activity against several cancer cell lines (Magiatis et al., 2001). These results led the authors to the fractionation of the methanolic extracts by medium pressure liquid chromatography (MPLC), obtaining an inactive fraction $\left(\mathrm{GI}_{50}>400\right)$, containing mainly sugars, and a fraction with increased cytotoxicity when compared to the total methanolic extracts. For the two species of $C$. hypocistis studied by Magiatis and co-workers, methanolic extracts exhibited $\mathrm{GI}_{50}$ of 100 and $98 \mu \mathrm{g} / \mathrm{mL}$ for human mammary adenocarcinoma (MDA-MB-231), in contrast with $\mathrm{GI}_{50}$ of 75 and $77 \mu \mathrm{g} / \mathrm{mL}$ for the cytotoxic active fraction. Similar results were obtained for human bladder transitional cell carcinoma (BC3c), 110 and $105 \mu \mathrm{g} / \mathrm{mL}$, in contrast with 71 and $67 \mu \mathrm{g} / \mathrm{mL}$ for the active fraction (Magiatis et al., 2001). The authors attributed this cytotoxic activity to hydrolysable tannins, without any obvious dependence on their molecular weights. Although in the present work different cell lines were used, both studies exhibited a similar range of $\mathrm{GI}_{50}$ regarding total extracts analysis. Because porcine hepatocytes are close to human hepatocytes in terms of metabolism and ammonia elimination, the four $C$. hypocistis extracts were tested for their hepatotoxic activity on non-tumour porcine liver cells (PLP2) (Table 5), and up to the maximal tested concentration $(400 \mu \mathrm{g} / \mathrm{mL}$ ) no toxicity was observed (Shi et al., 2016).

\subsection{Anti-inflammatory activity}

Macrophages play an essential role in the anti-inflammatory process and can be activated by interferon gamma (IFN- $\gamma$ ), interleukins (IL-4, IL-10, IL-13), transforming growth factor beta (TGF- $\beta$ ), and some structures from pathogenic microorganisms such as lipopolysaccharides (LPS) (Pohanka et al., 2011). During pathogen invasion, immunocytes secrete inflammatory mediators, such as nitric oxide (NO) and prostaglandin E2 (PGE2), via the inducible nitric oxide synthase (iNOS) and cyclooxygenase-2 (COX-2). iNOS and COX-2 are involved in tumour progression through various mechanisms, including inhibition of apoptosis, stimulation of angiogenesis and promotion of tumour cell proliferation (Guo et al., 2014). All the four C. hypocistis extracts successfully reduced the expression of the anti-inflammatory enzyme iNOS, in LPS-activated murine macrophages. NO reduction was measured employing a Griess reagent system kit and expressed as lower IC $_{50}$ values (Table 5). Among all extracts, the petals extract (PCH) showed the highest inhibitory effects in NO production by LPS-stimulated RAW264.7 cells $\left(\mathrm{IC}_{50}=127 \mu \mathrm{g} / \mathrm{mL}\right)$, followed by SCH $\left(\mathrm{IC}_{50}=127 \mu \mathrm{g}\right.$ / $\mathrm{mL}), \mathrm{CH}\left(\mathrm{IC}_{50}=136 \mu \mathrm{g} / \mathrm{mL}\right)$, and $\mathrm{NCH}\left(\mathrm{IC}_{50}=277 \mu \mathrm{g} / \mathrm{mL}\right)$. To the authors' best knowledge, this is novel study regarding the anti-inflammatory activity of $C$. hypocistis and thus no comparisons could be performed.

\section{Conclusion}

In this study, the chemical fingerprint of Cytinus hypocistis (L.) L. hydroethanolic extracts was determined and its antioxidant, antibacterial, antidiabetic, anti-tyrosinase, anti-proliferative, hepatotoxic, and anti-inflammatory properties evaluated. A total of 17 phenolic compounds were identified, being galloyl-bis-HHDP-glucose, digalloylbis-HHDP-glucopyranose, and trigalloyl-bis-HHDP-glucose the most abundant. In absolute terms, SCH was the extract exhibiting higher antibacterial, antidiabetic, anti-tyrosinase, and anti-proliferative activity, followed by the PCH extract. Regarding the anti-inflammatory and antioxidant properties, PCH exhibited the best results. Although for the four studied samples the 17 identified phenolic compounds were the same, its concentration was higher in the petals extract, followed by the stalks, being these the two parts of $C$. hypocistis unveiling the strongest colours. These results point a potential correlation between the phenolic profile of $C$. hypocistis and its properties. All these bioactive effects, with no evidence of cytotoxicity in a non-tumour cell line, could make this plant ideal to be explored for the development of herbal formulations and bio-based ingredients. For its bioactivity validation and mechanism investigation, further studies on fractionation, isolation and characterization of compounds of the extracts of $C$. hypocistis are currently under way.

\section{Author contributions}

Conceptualization, A.R.S., L.B., and I.C.F.R.F; Methodology, A.R.S.; J.P., M.I.D., R.C.C., M.J.A., A.M., L.B., and I.C.F.R.F; Investigation, A.R.S.; J.P., and L.B; Formal analysis, A.R.S., J.P., L.B., I.C.F.R.F.; Funding acquisition, I.C.F.R.; Project administration, L.B., P.A.G., and I.C.F.R.; Writing—original draft, A.R.S.; J.P., and L.B.; Writing—review and editing J.P., A.M., L.B., P.A.G., and I.C.F.R.F.

\section{Declaration of competing interest}

The authors declare that they have no known competing financial interests or personal relationships that could have appeared to influence the work reported in this paper.

\section{Acknowledgements}

The authors are grateful to the Foundation for Science and Technology (FCT, Portugal) and European Regional Development Fund (FEDER) under Programme PT2020 for financial support to CIMO (UID/AGR/00690/2019). L. Barros, J. Pinela, M.I. Dias and R.C. Calhelha thank the national funding by FCT, P.I., through the institutional scientific employment program-contract for their contracts. The authors are also grateful to FEDER-Interreg España-Portugal programme for financial support through the project 0377_Iberphenol_6_E and TRANSCoLAB 0612_TRANS_CO_LAB_2_P.

\section{References}

Balunas, M.J., Kinghorn, A.D., 2005. Drug discovery from medicinal plants. Life Sci. 78, 431-441.

Bessada, S.M.F., Barreira, J.C.M., Barros, L., Ferreira, I.C.F.R., Oliveira, M.B.P.P., 2016. Phenolic profile and antioxidant activity of Coleostephus myconis (L.) Rchb.f.: an underexploited and highly disseminated species. Ind. Crops Prod. 89, 45-51.

Calani, L., Beghè, D., Mena, P., Del Rio, D., Bruni, R., Fabbri, A., Dall'Asta, C., Galaverna, G., 2013. Ultra-HPLC-MS ${ }^{n}$ (Poly)phenolic profiling and chemometric analysis of juices from ancient Punica granatum L. cultivars: a nontargeted approach. J. Agric. Food Chem. 61, 5600-5609.

Carocho, M., Barros, L., Bento, A., Santos-Buelga, C., Morales, P., Ferreira, I.C.F.R., 2014. Castanea sativa Mill. Flowers amongst the most powerful antioxidant matrices: a phytochemical approach in decoctions and infusions. BioMed Res. Int. 2014, 232956.

Chen, C.-H., Chan, H.-C., Chu, Y.-T., Ho, H.-Y., Chen, P.-Y., Lee, T.-H., Lee, C.-K., 2009. Antioxidant activity of some plant extracts towards xanthine oxidase, lipoxygenase and tyrosinase. Molecules 14, 2947-2958.

Draelos, Z.D., 2007. Skin lightening preparations and the hydroquinone controversy. Dermatol. Ther. 20, 308-313.

Gali-Muhtasib, H., Hmadi, R., Kareh, M., Tohme, R., Darwiche, N., 2015. Cell death mechanisms of plant-derived anticancer drugs: beyond apoptosis. Apoptosis 20, 1531-1562.

Graça, V.C., Barros, L., Calhelha, R.C., Dias, M.I., Carvalho, A.M., Santos-Buelga, C., Ferreira, I.C.F.R., Santos, P.F., 2016. Chemical characterization and bioactive properties of Geranium molle L.: from the plant to the most active extract and its phytochemicals. Food Funct. 7, 2204-2212.

Guimarães, R., Barros, L., Dueñas, M., Calhelha, R.C., Carvalho, A.M., Santos-Buelga, C., Queiroz, M.J.R.P., Ferreira, I.C.F.R., 2013. Nutrients, phytochemicals and bioactivity of wild Roman chamomile: a comparison between the herb and its preparations. Food Chem. 136, 718-725.

Guo, Y., Sakulnarmrat, K., Konczak, I., 2014. Anti-inflammatory potential of native Australian herbs polyphenols. Toxicol. Rep. 1, 385-390.

Hofmann, T., Nebehaj, E., Albert, L., 2016. Antioxidant properties and detailed polyphenol profiling of European hornbeam (Carpinus betulus L.) leaves by multiple antioxidant capacity assays and high-performance liquid chromatography/multistage electrospray mass spectrometry. Ind. Crops Prod. 87, 340-349.

Khalid, E.B., Ayman, E.-M.E.-K., Rahman, H., Abdelkarim, G., Najda, A., 2016. Natural products against cancer angiogenesis. Tumor Biol. 37, 14513-14536.

Kim, Y.-J., Uyama, H., 2005. Tyrosinase inhibitors from natural and synthetic sources: structure, inhibition mechanism and perspective for the future. Cell. Mol. Life Sci. 62, 1707-1723.

Leroux-Stewart, J., Rabasa-Lhoret, R., Chiasson, J.-L., 2015. $\alpha$-Glucosidase inhibitors. In: International Textbook of Diabetes Mellitus. John Wiley \& Sons, Ltd, Chichester, UK, 
pp. 673-685.

Les, F., Venditti, A., Cásedas, G., Frezza, C., Guiso, M., Sciubba, F., Serafini, M., Bianco, A., Valero, M.S., López, V., 2017. Everlasting flower (Helichrysum stoechas Moench) as a potential source of bioactive molecules with antiproliferative, antioxidant, antidiabetic and neuroprotective properties. Ind. Crops Prod. 108, 295-302.

Liberal, J., Costa, G., Carmo, A., Vitorino, R., Marques, C., Domingues, M.R., Domingues, P., Gonçalves, A.C., Alves, R., Sarmento-Ribeiro, A.B., Girão, H., Cruz, M.T., Batista, M.T., 2015. Chemical characterization and cytotoxic potential of an ellagitanninenriched fraction from Fragaria vesca leaves. Arab. J. Chem. https://doi.org/10. 1016/j.arabjc.2015.11.014. Article (in press).

Lockowandt, L., Pinela, J., Roriz, C.L., Pereira, C., Abreu, R.M.V., Calhelha, R.C., Alves, M.J., Barros, L., Bredol, M., Ferreira, I.C.F.R., 2019. Chemical features and bioactivities of cornflower (Centaurea cyanus L.) capitula: the blue flowers and the unexplored non-edible part. Ind. Crops Prod. 128, 496-503.

Lü, J.-M., Lin, P.H., Yao, Q., Chen, C., 2010. Chemical and molecular mechanisms of antioxidants: experimental approaches and model systems. J. Cell Mol. Med. 14, 840-860.

Magiatis, P., Pratsinis, H., Kalpoutzakis, E., Konstantinidou, A., Davaris, P., Skaltsounis, A.-L., 2001. Hydrolyzable tannins, the active constituents of three Greek Cytinus Taxa against several tumor cell lines. Biol. Pharm. Bull. 24, 707-709.

Maisetta, G., Batoni, G., Caboni, P., Esin, S., Rinaldi, A.C., Zucca, P., 2019. Tannin profile, antioxidant properties, and antimicrobial activity of extracts from two Mediterranean species of parasitic plant Cytinus. BMC Complement Altern. Med. 19, 82.

Mena, P., Calani, L., Dall'Asta, C., Galaverna, G., García-Viguera, C., Bruni, R., Crozier, A., Del Rio, D., 2012. Rapid and comprehensive evaluation of (poly)phenolic compounds in pomegranate (Punica granatum L.) juice by UHPLC-MS ${ }^{\mathrm{n}}$. Molecules 17, 14821-14840.

Niu, C., Aisa, H.A., 2017. Upregulation of melanogenesis and tyrosinase activity: potential agents for vitiligo. Mol. A J. Synth. Chem. Nat. Prod. Chem. 22, 1303.

Okuda, T., Ito, H., 2011. Tannins of constant structure in medicinal and food plantshydrolyzable tannins and polyphenols related to tannins. Molecules 16, 2191-2217.

Owen, R.W., Haubner, R., Hull, W.E., Erben, G., Spiegelhalder, B., Bartsch, H., Haber, B., 2003. Isolation and structure elucidation of the major individual polyphenols in carob fibre. Food Chem. Toxicol. 41, 1727-1738.

Petersen, M., Hans, J., Ulrich, M., 2010. Biochemistry of Plant Secondary Metabolism. Wiley-Blackwell, Oxford, UK.

Phaniendra, A., Jestadi, D.B., Periyasamy, L., 2015. Free radicals: properties, sources, targets, and their implication in various diseases. Indian J. Clin. Biochem. 30, 11-26.

Phillipson, J.D., 2007. Phytochemistry and pharmacognosy. Phytochemistry 68, 2960-2972.

Pires, T.C.S.P., Dias, M.I., Barros, L., Alves, M.J., Oliveira, M.B.P.P., Santos-Buelga, C., Ferreira, I.C.F.R., 2018. Antioxidant and antimicrobial properties of dried Portuguese apple variety (Malus domestica Borkh. cv Bravo de Esmolfe). Food Chem. 240, 701-706.

Pohanka, M., Snopkova, S., Havlickova, K., Bostik, P., Sinkorova, Z., Fusek, J., Kuca, K., Pikula, J., 2011. Macrophage-assisted inflammation and pharmacological regulation of the cholinergic anti-inflammatory pathway. Curr. Med. Chem. 18, 539-551.

Rozas, O., Contreras, D., Mondaca, M.A., Pérez-Moya, M., Mansilla, H.D., 2010.

Experimental design of Fenton and photo-Fenton reactions for the treatment of ampicillin solutions. J. Hazard Mater. 177, 1025-1030.

Salminen, J.-P., Ossipov, V., Loponen, J., Haukioja, E., Pihlaja, K., 1999. Characterisation of hydrolysable tannins from leaves of Betula pubescens by high-performance liquid chromatography-mass spectrometry. J. Chromatogr. A 864, 283-291.

Sentandreu, E., Cerdán-Calero, M., Sendra, J.M., 2013. Phenolic profile characterization of pomegranate (Punica granatum) juice by high-performance liquid chromatography with diode array detection coupled to an electrospray ion trap mass analyzer. J. Food Compos. Anal. 30, 32-40.

Shao, L.-L., Wang, X.-L., Chen, K., Dong, X.-W., Kong, L.-M., Zhao, D.-Y., Hider, R.C., Zhou, T., 2018. Novel hydroxypyridinone derivatives containing an oxime ether moiety: synthesis, inhibition on mushroom tyrosinase and application in antibrowning of fresh-cut apples. Food Chem. 242, 174-181.

Shi, X.-L., Gao, Y., Yan, Y., Ma, H., Sun, L., Huang, P., Ni, X., Zhang, L., Zhao, X., Ren, H., Hu, D., Zhou, Y., Tian, F., Ji, Y., Cheng, X., Pan, G., Ding, Y.-T., Hui, L., 2016. Improved survival of porcine acute liver failure by a bioartificial liver device implanted with induced human functional hepatocytes. Cell Res. 26, 206-216.

Silva, A.R., Fernandes, Â., García, P.A., Barros, L., Ferreira, I.C.F.R., Silva, A.R. Fernandes, Â., García, P.A., Barros, L., Ferreira, I.C.F.R., 2019. Cytinus hypocistis (L.) L. subsp. macranthus Wettst.: nutritional characterization. Molecules 24, 1111.

Souilem, F., Fernandes, Â., Calhelha, R.C., Barreira, J.C.M., Barros, L., Skhiri, F., Martins, A., Ferreira, I.C.F.R., 2017. Wild mushrooms and their mycelia as sources of bioactive compounds: antioxidant, anti-inflammatory and cytotoxic properties. Food Chem. 230, 40-48.

Spínola, V., Castilho, P.C., 2017. Evaluation of Asteraceae herbal extracts in the management of diabetes and obesity. Contribution of caffeoylquinic acids on the inhibition of digestive enzymes activity and formation of advanced glycation end-products (in vitro). Phytochemistry 143, 29-35.

Stojković, D., Petrović, J., Soković, M., Glamočlija, J., Kukić-Marković, J., Petrović, S., 2013. In situ antioxidant and antimicrobial activities of naturally occurring caffeic acid, $p$-coumaric acid and rutin, using food systems. J. Sci. Food Agric. 93, 3205-3208.

Tan, H.P., Ling, S.K., Chuah, C.H., 2011. Characterisation of galloylated cyanogenic glucosides and hydrolysable tannins from leaves of Phyllagathis rotundifolia by LC-ESI MS/MS. Phytochem. Anal. 22, 516-525.

Wyrepkowski, C., Gomes da Costa, D., Sinhorin, A., Vilegas, W., De Grandis, R., Resende, F., Varanda, E., dos Santos, L., 2014. Characterization and quantification of the compounds of the ethanolic extract from Caesalpinia ferrea stem bark and evaluation of their mutagenic activity. Molecules 19, 16039-16057.

Yin, Z., Zhang, W., Feng, F., Zhang, Y., Kang, W., 2014. $\alpha$-Glucosidase inhibitors isolated from medicinal plants. Food Sci. Hum. Wellness 3, 136-174.

Zucca, P., Pintus, M., Manzo, G., Nieddu, M., Steri, D., Rinaldi, A.C., 2015. Antimicrobial, antioxidant and anti-tyrosinase properties of extracts of the Mediterranean parasitic plant Cytinus hypocistis. BMC Res. Notes 8, 562 